\title{
Autofictional themes, Practices and Strategies in View of the Construction of Intercultural Values at the University of Swaziland.
}

\author{
Karen Ferreira-Meyers, University of Swaziland,
}

\begin{abstract}
:
This article explores the notion of autofiction/faction: a post-modern literary concept which represents a blend of fact and fiction. At the same time, the paper wants to draw the reader's attention on the pedagogical possibilities of autofictional writing in the teaching of literature at the University of Swaziland. The notion of interculturality, with its goal of creating understanding of and among people, while safeguarding the relative identities of the actors involved, guides the analysis of postmodern feminine writing in the form of three Francophone women authors, C. Beyala, N. Bouraoui and A. Nothomb. Beyala writes autofiction from a feminist perspective, hers is the struggle for recognition of women rights and women's autonomy within a patriarchal society. Bouraoui came to autofiction from a psychoanalytical perspective, which makes her a descendant from Doubrovsky, the inventor of the autofiction neologism. Nothomb proposes a very personal and cathartic relationship to writing through which she wished to reach women in general. In conclusion, the article suggests the benefits of the analysis of the concept of autofiction as well as of the themes and language used in autofictional texts to university students in Swaziland because they promote intercultural understanding and acceptance.
\end{abstract}

\section{Introduction}

Questions of identity are universal questions; they form part of those research topics that are of interest to students and lecturers both, and to those studying linguistics and literature at the University of Swaziland, in particular. Interculturality is defined as the set of psychological, relational and institutional processes generated by the interactions of different cultures in a mutual exchange situation, to safeguard the relative cultural identity of the actors involved. In literature, the concept has been applied for many years, more so within postmodern writing, in particular in those texts written "outside the Western cultural space". In Africa, for example, "true intercultural experimentation laboratories" exist (Lüsebrink, 1997: 20). In order to practice an intercultural pedagogy, with an appropriate intercultural metadiscourse, one has to start from the Self to reach the Other(s), analyse the Other to better understand the self. In interpreting intercultural pedagogy, the following two are basic presumptions:

1. cultural relativism: According to Cohen-Emérique1, "All cultures are

${ }^{1}$ Cohen-Emerique M., 1993, "La formation des enseignants: pour une approche interculturelle" dans "La pluralité culturelle dans les systèmes éducatifs européens en 1993” - Proceedings from the Nancy symposium -January 1992. 
equal, in spite of their differences; they are all geared to a given ecological, economic, technological and social context, and each presents a scenario of human life."

2. the principle of autonomy of conscience: According to Camillieri², “(...) if individuals are convinced of the soundness of their perceptions and values, even if we are convinced of the contrary, we have no right to impose ours upon them (principle at the basis of the Declaration of the Rights of Man)."

Among various objectives, which include the exchange of views, the comparison of habits and frames of reference, the heightened understanding of social and educational problems relating to cultural diversity, the ones in connection with problem-solving, cooperation in group enterprises, the ability to listen to the Others and to show critical thought are those needing particular attention and development.

An intercultural approach is often marked by three stages: de-centring, penetrating the other's system and negotiation ${ }^{3}$. When one de-centres, one takes a more distant view of oneself, in order to realize what is relative in one's own world and culture. With an "attitude of opening up, a personal effort of enquiry about the main themes which are shaped around basic systems of reference and fundamental signs that are interpreted and blended in a unique way by each individual", any person can penetrate the other's cultural system, while the third stage, negotiation, refers to a process followed in order to reach what has been termed 'urbanity' by Jean Remy: "To develop a cosmopolitan attitude in an urban situation where different ethnic groups coexist (. . ) implies a conception of urban life which runs counter to the idea of placing people in a uniform mould. (...) Cosmopolitanism is not just a problem of cultural open-mindedness and preoccupation with the problems of the Other. It works insofar as we can see to what extent each person contributes to the dynamism of the whole." (Remy, J. ${ }^{4}$ 1990: 103-104).

Postcolonial, postmodern autobiographical and autofictional (faction) writing has a hybrid « $\mathrm{I} »$ as its object ; by its very nature it focusses on its cultural implications, while analysing different conceptions of human identity as determined by history and culture. (own translation, www.limag.refer.org/Theses/RichterFrancais.htm).

The identity of the Self is incessantly represented by all the fictions that are told by

${ }^{2}$ Camillieri C., 1993, Le relativisme, du culturel à l'interculturel, dans L'individu et ses cultures, Collectif, L'Harmattan, coll. Espaces interculturels, Paris, p.36. Translation of passage taken from: http://www.lmg.ulg.ac.be/articles/intercult en.html\#ancre60956, accessed on 3 November 2008.

${ }^{3}$ This is also the approach proposed on http://www.lmg.ulg.ac.be/articles/intercult en.html\#ancre 74141.

${ }^{4}$ Remy, J., dans "Immigration et nouveaux pluralismes - une confrontation de sociétés", coll. (sous la direction de BASTENIER A. et de DASSETTO F.), Editions Universitaires et De Boeck Université, Bruxelles, 1990.

${ }^{5}$ We borrow this expression from B. De Meyer: "donner une voix aux aphones sociaux" (2008: 47). 
the subject to the Other about herself, or by the stories the subject tells herself about the Other. The narrative identity of the individual or collective Self is build on the capability to communicate with the Other within modern society. A new perspective of the identity problem, in particular of the identity of the narrator, demands that we transcribe our history, not only to become more conscient of our position within society, but also to construct the dialogue with the Other.

It is from this viewpoint that we would like to analyse how feminine autofictional writers have been able to translate their 'alterity' and to enter into a meaningful, intercultural dialogue with the Other (the other culture, the reader, ...). From our perspective, it is important to continue to introduce feminine Francophone (African and European) writers in the study of literary texts, by giving "a voice to the social voiceless" $"$ as in mainly patriarchal societies the portraying of the marginalised woman and her quest for an identity within them has to counterbalance a traditional representation of the superiority of men. For the purposes of this article, and because of their relevance in today's literature, we have chosen Calixthe Beyala (Cameroonianborn, lives in France), Nina Bouraoui (Algerian-born, lives in France), Amélie Nothomb (Belgian-born, lives in Belgium and France).

In line with the objectives of an intercultural pedagogy as described by Flye Sainte Marie, i.e. intercultural pedagogy is "geared essentially to a positive development of views and attitudes in relation to the Other one who is different from oneself" Autofiction from a theoretical perspective, Francophone literature and the place of women

Autofiction, a French neologism from the end of the 1970's, refers to a mixture of autobiography and fiction. Because autofiction is the natural heir of the « Nouveau Roman » and postmodern writing, it incorporates such characteristics as self-reflexivity, intertextuality, the blending of genres, the destruction of the mimetic illusion, a more 'legible' narrative discourse (Lamontagne 1998: 63) and often the triangular identity of author-narrator-character ${ }^{7}$. An autofictional text can often be read from two angles: either as a novel or as an autobiographical text ${ }^{8}$. Hubier (2005: 122) talks about the

${ }^{6}$ Flye Sainte Marie A., 1994, Pour une pratique pédagogique interculturelle en milieu scolaire centrée sur les images et les attitudes, dans VERMES G. et FOUKIER M., Ethnicisation des rapports sociaux. Racismes, nationalismes, ethnicismes et culturalismes. volume III, L'Hannattan, coll. Espaces interculturels, Paris, p. 104. Translation of passage taken from: http://www.lmg.ulg.ac.be/articles/intercult en.html\#ancre74141, accessed on 3 November 2008.

${ }^{7}$ Some novels written by Beyala can not be seen as autofictions. Neverhteless, we think they can easily feature in this article because of what she herself proclaims in an interview with Tirthankar Chanda (Notre Librairie 2003): "I am at the same time all my characters. I am Irène Fofo, I am Ousmane. I cannot construct a character that is not me. It is, at the same time, not me, because I could not have had all these experiences". Clearly a blend of real facts and fiction, typical of autofiction or faction.

${ }^{8}$ This type of text is called amphibious. According to Hubier (2003: 125), the classical grammarians used this term to include a text which could have two possible interpretations. 
reorganisation of a text by its writer according to her life experiences. This literary variant of the literature of the Self translates clearly what Serge Doubrovsky, the inventor of the neologism expresses:

Autofiction, it is fiction in which I have, as a writer, decided to give myself, incorporating the experience of psychanalysis, not only from a thematic point of view but also in the production of the text (Doubrovsky quoted by Hubier, op.cit. p. 126)

Vincent Colonna's definition of autofiction best reflects the representation of the Self in literature; autofiction, according to Colonna, includes

all the literary compositions in which a writer uses his own name (or any name which the reader can easily identify as the author) in a story that has the characteristics of fiction, either by an unreal content, by a traditional conformation (novel, comedy) or by a contract « signed » with the reader. (Colonna 2004: 70-71)

Criticised by some as being « the symptom of an inspirational breakdown » with as its main characteristic " an indulgent and narcisstic attitude », condemned by others « of all the wrongdoings formerly linked to the autobiographical novel: navelgazing, shamelessness, exhibitionism, creative impotence, etc." (Colonna 2004: 199), autofiction allows for an «I » who takes responsibility before her readers. This "I" clashes with our ideas of reality and fiction ${ }^{9}$, of sincerity and lies, of real and false, all those dialectically opposed concepts supposedly indispensable to our comprehension of the world. The frontier between imaginary and real is fragile and sometimes indiscernible. According to Lejeune, expert on autobiographical writing,

what is new is the frequency of the literary games that tend to abolish the frontiers between what was lived and experienced first-hand and what was invented [...] Is this an innovation of the autobiography or what was formerly called the 'roman personnel'? One does no longer really know. We look for new words to describe this in-between. In the United States, the portmanteau word "faction", which was called, in a more developed manner, "factual fictions" by Albert E. Stone. In France Serges [sic] Doubrovsky suggested to call these texts "autofiction" for which he devised the following definition: "Fictions of events and facts that are real: autofiction has confided language to an adventure, outside wisdom and outside the syntax of the novel, be it traditional or "nouveau roman". It is a new rule: to try to be exact while allowing yourself to reconstruct, not to use foul play on the facts by playing with words, while following the flow of language. Everything is true and everything is re-created. (Lejeune 1988: 80). 
In French, several names have been given to this mixture of fiction and reality: Jean Ricardou (1982: 188) talks about 'biotextual', other describe autofiction/faction as a biofictive text (Francis 2003: 117), "surfiction" (Federman, quoted by Viollet 1993: 195), "experimental fiction" or "imaginary autobiography" (op.cit. 195), still others as "New Autobiography" (own translation; www.limag.refer.org/Theses/ RichterFrancais.htm). While several definitions and variations of the autofictional genre exist ${ }^{10}$, the central questions linked to autofiction are those primordial for all writing of the Self, namely that of construction of identity, that of the link between autobiography and psychanalysis, that of the writing tools at the disposal of the author allowing the unknown and the 'otherness' to emerge. Autofiction, « frictional literature ", on the border of existence within reality and imaginary life, between autobiography and novel (Doubrovsky quoted by Hubier 2003: 126), is, therefore, the ideal form to talk about subjects like uprooting and rifts that possibly occur among people from different cultural spheres. Often, as is the case in A. Nothomb, C. Beyala and N. Bouraoui's writing, the expression of a personal experience in an autofictional text underpins a collective speech in which the singular " me » represents the voice of a group of people ${ }^{11}$.

Reading ${ }^{12}$ is linked to adhesion and assimilation phenomena: "the one essential phenomenon which underlies [any literary text] in its relationship with ourselves [is] the identification phenomenon phénomène" (Georges Poulet quoted by Langlade 2000: 2). According to Langlade (2000: 2), the assimilation of the reader to the characters and events told in a novel is encouraged by the original mimetic connection which fictional writing has in general.

In the analysis of autofictional writing, it is therefore primordial for students/readers to understand that the reality, because it has been transformed into fiction by the text, will force the reader to discover action and thought models foreign to their own universe. This constitutes one of the main goals of intercultural education as it is a "pedagogical movement that stresses justice, equity and understanding of diversity within multicultural democratic societies" (Lasonen 2005: 56) such as we would like to see it exist in Swaziland.

As stated in our introduction, our focus is on texts produced by women, mainly because in the environment we live in, women are still discriminated against. By

\footnotetext{
${ }^{9}$ The debate between fiction, verisimilitude and reality in literature cannot be held here. It has to be stressed, however, that it is a extremely important debate to be undertaken with the students when researching literature of the Self.

${ }^{10}$ According to the narrowest definition, an autofiction is a text in which the author uses his own name but invents numerous parts of his life. According to another definition, autofictional writing is the postmodern form of autobiographical writing, pointing to hybrid works, based on a contradictory pact, blend of invention and sincerity. According to a third, it refers to the deepest approach, inherent to the act of writing itself.

${ }^{11}$ Certain novelists bore us with their self-centred navel-gazing texts, but, as usual in the pedagogical work of a teacher, it will be necessary to carefully choose texts that are both creative and allow for a perpetual re-inventing of our identities.
} 
analyzing the textual production of women, we hope to raise awareness about their situation, to open up the discussion and the interaction between women and men in society, and to propose solutions for collaboration and unity.

\section{Self-mockery and humour: strategies of autofictional writing}

Several characteristics of the autofictions of Beyala, Bouraoui and Nothomb are of common origin, even though the women writers have different geographical, cultural, educational and social backgrounds. All three of them utilise the first person singular, I, who not be considered as a being which exists 'before language' but rather as a literary construct, within language. The identities at play in their oeuvre is constructed within language, for Beyala as part of a feminist revolt, for Bouraoui with psychoanalysis as its starting point and for Nothomb strongly linked to her past when she struggled with anorexia.

We have already stressed that fiction and reference to the real world are no longer antagonistic categories in autofictions, but the fictional part, which we can equate to the construction of the Self through language, is a manner of representation. (own translation, www.limag.refer.org/Theses/RichterFrancais.htm).

Humour and self-mockery form an integral part of the writings of these young women. Begag (quoted in Schleppe 2003: 133) explains that human reduces the intercultural distance and can be seen as the ultimate integration tool because humour is used to infiltrate and understand cultures. In the same vein, Begag (Schleppe 2003: 133) explains his invented terminology of "humerous telescoping or concertinaing" (in French, téléscopage humoristique) as follows:

The questions of immigration, strangers, Others can generate
feelings of insecurity and distance between 'us' and the 'others'.
Humour, as soon as it allows for adhesion by the audience to
diversity, offers a breathing space, a space of 'lightness' and
security, in brief, a space of encounters. Humour thus reduces
the gap between identities, or said otherwise, it creates a
common identification space. (own translation)

With these general observations, we now turn to the analysis of the autofictional writing of each individual author and what it can offer our students.

12 During a national seminar on recent trends in the Teaching of French, held in Paris, 23-25 October 2000, Gérard Langlade introduced three important approaches to reading, namely subjective reading which refers to the personal interpretation and intimate appreciation of a written work, critical reading which presupposes an interpretation based on text analysis and sholarly reading of a university level qui inscribed the reading in a cultural perspective" (own translation; Langlade 2000: 1).

${ }^{13}$ In the case of A. Nothomb, numerous humoristic strategies can be found in her oeuvre. In Stupeur et Tremblements (1999), for example, she uses euphemisms, antiphrasis, hyperbole and hero-comic expressions in dialogue and narration (Narjoux 2004: 78-79). 


\section{Calixthe Beyala: feminist activism and autofictional writing}

African female authors, from their position of marginalized writers produce literature that 'exhibits' and 'provokes' because they have been 'silenced' for long periods of time (De Meyer, 2008: 45). Wanting to offer a viewpoint from the inside, their writing is often confined to autobiographical, autofictional and other 'intimate' forms which include the use of the first person singular.

Cameroonian-born female author Calixthe Beyala's œuvre includes two political essays, Lettre d'une Africaine à ses sæurs occidentales (1995) et Lettre d'une Afrofrançaise à ses compatriotes (2000), and a series of autofictional and fictional novels. Race, race relations and gender are part of the recurrent topics in all her texts. She strongly criticizes African states for their postcolonial dependency and their 'fixation' on the former colonizer as the main reasons for economic and social underdevelopment found in most modern African nations. In her analysis of the 1994 novel Assèze l'Africaine, Schleppe (2003) explains how Beyala deconstructs human nature, selfperception, identity infiltration, the identity construction of female sexuality in the postmodern society. The de-construction is mainly done using language: "Beyala's texts continually refer to their own creation, to the power of words, to the link between reality and fiction" (own translation, De Meyer 2008: 58). Indeed, Beyala has one of her main characters say the following: "je transformerai mes mensonges en vérité. Il suffit de les codifier avec précision, de les ciseler" (I will transform my lies in truth. It is enough to codify them with precision, to chisel/polish them, own translation, Tu t'appelleras Tanga, 1988: 36).

Already in 1988, in Tu t'appelleras Tanga, Beyala denounced not only the collapse of values but also the psychological trauma from which her heroines suffer. In particular, female excision is one of the main themes of this novel. For Nga Taba, the mother of the main character Tanga, the mercantile aspect of this type of female mutilation becomes more important than other, more traditional reasons. Excision, in Beyala's writing, turns out to be the easiest way for parents to 'appropriate' their daughter's body, like merchandise that follows a supply and demand curve. Nga Taba's reaction, the dancing and cries of joy she emits represent the benefits she will collect from Tanga's mutilation and translate Beyala's new interpretation of this 'ancient' tradition. Tanga submits to her mother's wishes; in this way, she raises the reader's awareness not only on the conditions of African childhood in the urban megalopolises, but also and above all on the conditions of the Black African woman so often victim to a phallocratic interpretation of tradition. (own translation; Ossouma 1995: 121).

In a similar vein, the title of Beyala's first autofiction C'est le Soleil qui m'a brûlée (1987), identifies the narrator: a Black woman who uses the first person singular to narrate her story. According to De Meyer (2008: 50), it is precisely "the affirmation of an identity which is not only the main character's identity, incarnating feminist claims and demands, but also the identity of a female novelist, with as distinctive signs the fact that she is black and female" (own translation) which makes this oeuvre interesting.

King (1993: 104) underlines the fact that Beyala's œuvre is the celebration of the woman as narrator of her own history. In this way, Beyala contributes to the road to independence by women and women writers in Africa. According to Gallimore, 
Beyala's multicultural agenda is also found in the blend of Western, Franco-French and African culture and imagery as exemplified by the "sound of the tam-tam, the sniggering of the African music instruments and the shouting of the griots" (own translation of Gallimore quoted by Schleppe 2003: 130).

\section{Nina Bouraoui: personal psychoanalytical struggle and autofiction ${ }^{1}$}

Writing in Nina Bouraoui's case establishes binary oppositions between the two poles of the identity, Algeria and France. She has "a double soul which produces open-mindedness" (Agar-Mendousse 2006: 19), one of the main objectives of an intercultural approach.

L'œuvre de Nina Bouraoui entre dans la catégorie textuelle de l'autofiction parce qu'elle en présente plusieurs caractéristiques ${ }^{14}$.

In Le garçon manqué (2000) as well as in Mes mauvaises pensées (2005), Bouraoui uses psychoanalysis, one of the fundamental strategies proposed by Doubrovsky ${ }^{15}$ when practising autofictional writing: conscientisations of an individual in a moment of childhood is represented by silences, modesty and decency, hatred, corporal torment, fear, traveling, love among women, etc. Among the topics Bouraoui uses in her autofictional writing, several of those mentioned above are of interest to our students.

\section{Amélie Nothomb: a Japanese passion}

Four novels of Nothomb's large œuvre ${ }^{16}$ can be described as autofictions: Le Sabotage amoureux (1993), Stupeur et Tremblements (1999), Métaphysique des Tubes (2000) and Ni d'Eve ni d'Adam (2007). Stupeur et Tremblements, which relates the year the narrator and main character spent in a Japanese ${ }^{17}$ enterprise, is by far Nothomb's most popular and influential autofiction to date. Already on the programme of various schools and universities in France, it allows critical analysis of topics such as the difference between autobiography and autofiction, recognition of the Self, limits of the Self, writing by and about women, etc. The use of the realistic viewpoint allows the author to present the fictional universe as close as possible to the real world (own

${ }_{14}$ The same observation at that made regarding the autofictive writing of Calixthe Beyala can be made here: the narration is done by an autodiegetic narrator, most often an anonymous 'I', but it is clear that the anonymity of the narrator "creates an empty space which the reader may fill by inconsciously, in his/her imagination, putting in the name of the author" (own translation, Rey quoted by Regaieg 1995: 123).

15 Serge Doubrovsky is generally accepted to be the theorist and inventor of the concept of autofiction.

${ }^{16}$ Amélie Nothomb has published, without fail, one novel a year, since her first novel Hygiène de l'Assassin, published in 1992

${ }^{17}$ Ms Nothomb was born in Japan in August 1967 and spent her first five years in the country of the rising sun. She then lived in various countries as her father was a Belgian ambassador, before going back to Japan between 1990 and 1992. She describes this period in two autofictions: Stupeur et Tremblement (1999) and Ni d'Eve ni d'Adam (2007). 
translation, Narjoux 2004: 71).

\section{Conclusion}

The above-mentioned intercultural dynamics at play in the literary œuvre of various Francophone female writers can, according to us, be of great benefit to university students in Swaziland. The autofictive practices by women represent "a powerful tool for socio-epistemological insertion for those who are normally voiceless in society or are excluded from official discourse and therefore also outside normed representations" (own translation; S. Smith quoted by Francis 2003: 117).

Transposed on a social scale, the comprehension of the dynamics of conflict can be of assistance in the understanding of and among people. Autofictional writers using the literary hybrid genre of the fictionalisation of the Self, where the Self and the Other coexist, speak of others while feigning to speak about the Self in order to rediscover the human condition of men, in which the honest man is a disinterested man (own translation, Million 2005: 8).

Beyala, Bouraoui and Nothomb all bring along this cultural diversity which is necessary to succesfully complete a discovery of the Other and an intercultural understanding. The analysis of their texts by our students will allow them to discover and recognize the Others while at the same time recognizing themselves. It will further permit awareness of value judgments and discovery of fundamental similarities and universal values which different cultures have, inevitably, in common.

\section{Références}

Agar-Mendousse, T. 2006. “ Fracturing the Self: Violence and Identity in Franco-Algerian Writing” in Violent Depictions Representing Violence Across Cultures, eds. Scarparo S. and McDonald S., Newcastle: Cambridge Scholars Publishing.

Benahmed, N.A. 2000. L'écriture de Nina Bouraoui: éléments d'analyse à travers l'étude de cinq romans, Université de Toulouse le Mirail (en ligne sur http://www.limag.refer.org/ Theses/BenmahamedMaitriseBouraoui.PDF, consulté le 16 juin 2008).

Beyala, C. 1987. C'est le soleil qui m'a brûlée. Paris: Stock.

1988. Tu t'appelleras Tanga, Paris: Stock.

1993. Assèze l'Africaine, Paris: Albin Michel.

Bouraoui, N. 2000. Le garçon manqué. Paris: Stock. 2005. Mes mauvaises pensées. Paris: Stock.

Colonna, V. 2004. Autofictions et autres mythomanies littéraires, Paris: Editions Tristram.

De Meyer, B. 2008. "Tu t'appelleras Beyala ou la vision de Calixthe", in French Studies in Southern Africa-Etudes françaises en Afrique australe, $\mathrm{N}^{\circ} 38,2008$, pp. 44-62.

Francis, C. 2003. "L'autofiction de France Daigle. Identité, perception visuelle et

réinvention de soi”, in Voix et Images, vol. 28, part 3, Montréal: Université du Québec, pp. 114-140.

Hubier S. 2003. Littératures intimes, les expressions du moi, de l'autobiographie à l'autofiction, Paris: Armand Colin.

King, A. 1993. "Calixthe Beyala et le roman féministe africain", in Carrefour de Cultures: mélanges offerts à Jacqueline Leiner, Tübingen.

Lamontagne, A. 1998. "Métatextualité postmoderne: de la fiction à la critique" in Etudes Littéraires, vol. 30, n³, été 1998. 
Langlade, G. 2000. "La lecture littéraire: savoirs, réflexion et sentiments" in Actes du

Séminaire national 'Perspectives actuelles de l'enseignement du français' (en ligne sur http:// www.discip.ac-caen.fr/la.reussite.en.seconde/IMG/pdf/actfranlanglade.pdf, consulté le 27 mai 2008).

Lasonen, J. 2005. "Réflexions sur l'Interculturalité par rapport à l'Education et au Travail" in Higher Education Policy, 18, 4, 2005, pp. 54-62.

Lejeune, Ph. 1988. "Peut-on innover en autobiographie?" in L'Autobiographie, Paris: Les Belles Lettres.

Lüsebrink, H.-J. 1997. "Domination culturelle et paroles résistantes" in Littérature et dialogue interculturel, Canada: Presses de 1’Université Laval.

Million, A. 2005. Réflexions autour de l'écriture de soi: le refus du psychologisme, Cahiers de l'Ecole, numéro 2, 2005: 8; en ligne sur http://www.cahiers-ed.org/ftp/cahiers2.html, consulté le 27 mai 2008).

Molkou, E. 2002. "L'autofiction, un genre nouveau?" in French Literature Series,

Beginnings in French Literature (edited by F. G. Henry), pp.155-168.

Ossouma, B.E. 1995. "Laideur et rire carnavalesque dans le nouveau roman africain", in Politique Africaine, 60 (en ligne sur www.politique-africaine.com/numeros/pdf/060117.pdf, consulté le 27 mai 2008).

Ouellette-Michalska, M. 2007. Autofiction et dévoilement de soi, Montréal: XYZ (Coll. "Documents").

Regaieg, N. 1995. De l'autobiographie à la fiction ou le je(u) de l'écriture. Etude de

l'Amour, la fantasia et d'Ombre sultane d'Assia Djebar. Doctorat, Paris: Université Paris-Nord.

Ricardou, J. 1988. Le théâtre des métamorphoses, Paris: Seuil.

Schleppe, B. E. 2003. Empowering New Identities in Postcolonial Literature by Francophone Women Writers, Ph.D. Disseration, University of Texas. (en ligne sur http://www.lib. utexas.edu/etd/d/2003/schleppebe032/schleppebe032.pdf, consulté le 27 mai 2008).

Viollet, C. 1993. "Raymond Federman: la voix plurielle" in Autofictions \& Cie. Nanterre: Publidix, pp. 195-201. www.limag.refer.org/Theses/RichterFrancais.htm, consulté le 27 mai 2008. 